\title{
Do Board Characteristics Matter to Insider Timing and Profitability in the US Market?
}

\author{
Bill Kiwia* \\ Institute of Finance Management, Po Box 3918 Dar es salaam Tanzania \\ *Corresponding author: Billkiwia477@hotmail.com
}

\begin{abstract}
In this paper I analyze the relationship between insider trading and corporate governance characteristics. Despite, the widely held view that insider trading significantly affects stock prices; little is known about what causes such market inefficiency and whether firm characteristics matters. This paper focuses on the impact of board structure towards insider trading and stock price efficiency. Using an event study methodology, this paper analyzes the influence of different board characteristics on insider profits as measured by share price abnormal returns. It also uses purchase ratio as a proxy for insider trading activities. Findings suggest that higher board independence, small board size and high debt levels have a significant influence towards reducing insider profits. The trading activities of insiders appear to have no significant relationship to the corporate governance characteristics of the firm. The overall results suggest that good governance reduces insider abnormal profits and increase stock price efficiency. With regards to insider trading activities we found little evidence suggesting corporate governance impact insider trading associated with future cash-flows. The study uses a sample of 250 firms from S\&P 500 Index from 2000 to 2005.
\end{abstract}

Keywords: insider trading, board-structure, asymmetry information theory

Cite This Article: Bill Kiwia, "Do Board Characteristics Matter to Insider Timing and Profitability in the US Market?” Journal of Finance and Economics, vol. 5, no. 1 (2017): 18-33. doi: 10.12691/jfe-5-1-3.

\section{Introduction}

This paper examines whether an effective internal corporate governance structure helps to reduce insider performance and trading activities in the capital markets. The overall consensus from the literature is that regulations, particularly federal regulations, have no or little effect on insider performance in stock investing [1]. Federal regulation is found to impact only the timing of insiders but failed to have an effect on insider performance $[2,3]$.

Most of this field research has focused on the role of federal regulations in insider trading and has ignored the influence of internal or corporate regulations in eliminating opportunistic insider trading $[4,5,6]$. Internal regulations, such as corporate policies, monitoring and company incentives, may in a way reduce asymmetric information between corporate insiders and outside investors. Better governed firms may also help to reduce the agency cost of information and may subsequently help to reduce opportunistic insider trading activities. This is the key goal of this paper that we would like find out if good internal governance structure have a deterrent effect towards insiders timing and performance in the capital market.

Recent studies have suggested that corporate governance through board structure increases information disclosure in terms of both quality and quantity $[7,8]$. In addition, good corporate governance has been found to reduce corporate fraud activities inside the corporation [9].
Further, evidence has suggested that good governance enhances board monitoring, increases accountability to management, enhances corporate performance and reduces the cost of financing $[10,11]$. On the other side studies showed that corporate insiders have been performing significantly higher than other investors from their stock transactions $[1,12,13,14]$. Their abnormal performance was discovered to range from few days following their transactions up to six months [1]. This defies strong form market efficiency and little is known on the reasons for such abnormal performance of insiders in the equity market. Further, the timing of insiders also raised some interest in the finance literature. Studies found that corporate insiders trade actively before close earnings announcements period and trade restrictions as well as after the announcement of corporate performance [2]. Further, they appear to trade as contrarian investors buying stocks actively when they perform poorly and sell them when they perform well $[3,15]$. Corporate insiders purchases of stocks after they performed poorly has attracted a number of studies to investigate factors behind such contrarian behaviour [16]. These studies explore the role of internal governance structure towards contrarian behaviour of insiders in the capital market.

In sum, it has been shown by many studies that in the presence of good governance, corporations become more transparent and hence they subsequently increase stock market efficiency. Whether good governance helps to increase stock market efficiency and transparency remains an unanswered question [17]. Corporate insider abnormal performance rejects the strong form market efficiency $[5,18,19]$. This will be an issue of concern to regulators as 
insider abnormal performance also signifies asymmetric information costs particularly for outside investors. While there is a little evidence on insider selling but insider purchase is associated with scepticism particularly following poor performance [20]. Evidence suggested the decision for insiders to purchase stocks after poor performance is signal of optimistic view of the company they have access to information and such may also sometimes associated with additional information that they have which is not available in the market. Capital market regulators (regulators) introduced a number of measures to prevent and reduce such advantages. Amongst the measures were introducing trading ban (e.g. in UK), requiring to disclose and file their transactions to the regulators (e.g. US) as well as severe fines for those who are in breach of insider trading laws. Whether these measures have deterred insider trading activities and their performance is still a debatable question. Similarly, these measures could function as external governance measures but what role are internal governance measures to influence insider performance and activities remains an open area of interests.

This paper offers insight into the effectiveness of these measures (regulation provision) as external governance measures as well as the role internal governance mechanism towards trading activities of insiders and their performance. This will raise an interest of research on the role of self-regulations of companies towards insider abnormal performance. Previous studies argued that there is a scanty researches that look at the role of corporate policies, rules and restrictions towards insider performance [6,21]. Effective corporate policies and restrictions depend with an effective governance structure particularly internal governance structure that will influence setting of appropriate policies and practices needed by the company [22]. We think this will be one of the earliest studies looking into that area and provide more insight on better of monitoring and regulating insiders in the capital market.

My result in Table 4 shows that share price reaction following insider purchase is significantly positive, and following insider selling the share price reaction is significantly negative. This is consistent with previous studies which argued that investors consider insider trading signalling important to their stock trading decisions [1,12,13,14,23]. Significant abnormal returns following insider purchasing and sales indicate that markets are still, at best, semi-strong in terms of market efficiency. CAR for purchase and sales were $2.85 \%$ and $0.16 \%$ respectively. This finding are similar to previous studies and concur with markets sentiments that consider insider purchase as an important signal whilst insider selling of stocks are more related with liquidity needs $[1,12,23]$.

I also found in my analysis that insider performance measured using CAR is negatively (positive) associated with board independence (board size). I found little evidence to support the influence of other board structure variables and insider performance in the capital markets. In addition, I found that firms with a higher debt level appear to have lesser insider performance compared to those with a larger debt level. These findings suggest that close monitoring and information disclosure affect corporate insider performance in the capital markets. Findings on trading activities show that board structure has little effect on the timing of insider trading in the capital markets (opportunistic insider trading activity). I use a purchase ratio to measure the extent of opportunistic trading activities taken by an insider in the capital markets.

I found that opportunistic trading activities by insiders are influenced more by contrarian factors than board structure. Book-to-market ratio and firm size appears to significantly influence the timing of insiders in the capital markets (see Table 9). These findings are consistent with some earlier studies by $[24,25,26]$. My results suggest that internal governance mechanism taken by firms may be effective in reducing the agency costs of information to investors when these investors are trading in the capital markets. Enhanced disclosures and close monitoring may be among the factors that contribute to lower stock performance from insiders. However, these internal governance mechanisms particularly board structure appear to have little or no effect on reducing opportunistic insider trading in the capital markets as the result show no relationship between purchase ratio and corporate board characteristics.

My study contributes to policy making as it recommends increased usage of independent (nonexecutive) directors and institutional investors as these individuals may help to mitigate information asymmetry between insiders and outside investors. I believe that a greater role should be given to independent directors and institutional investors in the monitoring of company management. Moreover, my findings show that board structure has little influence on preventing opportunistic insider trading activities. More studies are needed to investigate whether other aspects of corporate governance, such as managerial remunerations and institutional investors, have an influence on opportunistic trading activities by insiders. I also recommend the use of external preventive measures, such as trading bans, which may also help to prevent these activities.

The remainder of the paper is structured as follows. The next section explains the US regulatory framework. Section 3 develops hypotheses constructed from the existing insider trading and corporate governance literature. Section 4 discusses the sample construction and methodology used. Section 5 is the results analysis and section 6 is the final conclusion and policy implications.

\section{Regulatory Framework}

Following the Wall Street Crash of 1929, insider trading regulations grew substantially to promote stock market reputation. The United States Congress introduced a number of acts aimed at regulating insiders in the financial market. The SEA of 1934 and the amendment provisions from the Williams Act of 1966 were aimed at curtailing illegal insider trading and protecting minority shareholders against losses that they might incur while trading against informed insiders. These regulatory provisions state that any person who is in possession of material, non-public information is not allowed to trade, and any violation amounts to a criminal infraction [27]. Sections 10 and 14 both state that any person who is in 
possession of material, non-public information should abstain from trading or from disclosing such information. However, what constitutes 'material, non-public information' remains ambiguous and is not clearly defined by law $[19,28]$. It was expected that subsequent regulation would clarify these issues but instead introduced severe punishment. The Insider Trading and Securities Fraud Enforcement Act of 1988 rose the fines from $\$ 100,000$ to \$1 Million while the subsequent Sarbanes Oxley Act (SOX) of 2002 increased the period of imprisonment from 5 years to 10 years. Similarly the Act of 2002 reduced the disclosure period from 40 days to 1 day after the date of the transactions. Further, they introduced a trading ban period around retirement plan for directors (blackout period) to prevent directors from manipulating company performance.

The debate on the importance of all these regulations and whether they should be reduced remains still inconclusive. However, whether such regulations were effective changing the behaviour of corporate insiders in the US capital markets remains an issue of interest to investigate. Further an alternative approach for monitoring insiders in the capital market remain a very interesting area scantly researched see Table 1 for a summary of the researches on insider trading. Corporate governance may be an alternative option for monitoring insider trading activities in both stock and bonds (the current law remain silent on monitoring measures for bonds investment). The importance of corporate governance is that it may help to reduce agency costs associated with separation of ownership from control $[29,30]$. Whether such measures would also have an impact in reducing opportunistic insider trading activities and their abnormal performance remains to be seen in finance literature.

The separation of ownership from control resulted in agency costs between different stakeholders of the company [22]. The Anglo-Saxon model of wider held ownership structure resulted into asymmetric information between shareholders and management, and also between debt holders and shareholders as well as between large shareholders and minority shareholders [31]. This resulted in a number of problems such as free rider problem, principal agent problem and wealth distribution effect. Internal governance measures such independent directors, separation of chair and chief executive, debt finance were consider as effective tool to reduce asymmetric information between stakeholders and help to mitigate such agency costs.

\section{Construction of Hypotheses}

As I aforementioned earlier there were a number of regulations introduced to tackle illegal insider trading activities and enhance information disclosure in the US markets. However, there are some limitation to the existing legislation as mentioned earlier and perhaps such limitation could be overcome corporation self regulatory policy established within company framework [6]. Effective corporate self regulation occurs if there is good corporate governance as tool reduces agency cost of information.

Therefore the conceptual framework in corporate governance literature argues that good corporate governance help to reduce agency cost of information between stakeholders. In that perspective if corporate insider abnormal performance is attributed by asymmetric information corporate insiders and outside investors then will corporate governance reduce insiders abnormal performance and eventually reduce opportunistic insider trading activities in the capital market. Thus key hypotheses are;

H1: Is good corporate governance negatively associated with corporate insider trading activities associated with future cash flows?

H2: Is good corporate governance negatively associated with stock market reactions following insider transactions?

Table 1. Summary table of earlier studies on insider trading in US

\begin{tabular}{cl}
\hline Author & \multicolumn{1}{c}{ Issues } \\
\hline & $\begin{array}{l}\text { Is there a relationship between insider } \\
\text { trading and subsequent changes of }\end{array}$
\end{tabular}
trading and subsequent changes of rates of returns?

Jaffe (1974)

Finnerty (1976)

Seyhun (1986)

Ofek and Yermack (2000)

Lakonishok and Lee (2001)
Does insider trading provide useful signals to market traders?

Does insider trading have a relationship with the subsequent announcement of financial and accounting results?

Does stock price reacts following insider transactions? Can outsiders obtain abnormal profit from imitating insiders?

Does stock based compensation impacts managerial ownership?

Do insider transactions contain useful information about stocks?

\section{Findings}

Using a ratio of three trading (purchase or sell) to one of the opposite as a definition for insider trading suggests that abnormal returns were $17.5 \%$ more for purchase than sales in one year, $28.5 \%$ in 2 years. These findings suggest that purchase transactions have a stronger price reaction than sales of stock. Share price reactions are visible and significant following insider purchase or sale of stock. Insider profitability occurs before price jump or decline. The results suggested that regulation had little or no effect on insider performance.

Purchasing stocks by insiders is intensive in firms of small size, large earnings and large dividend payout. Insider selling of stocks is intensive in firms of large size, lower earnings and small dividend payout. In addition insider forecasting ability covers only the short-term. In summary corporate insider uses future financial information to trade.

Insider purchase of stock is followed by positive share price reactions, while inside selling of stock is followed by negative share price reactions. Insiders can predict future returns and profits from their transactions. Outsiders may also generate abnormal profit by following insider transactions but after taking into consideration transactions costs this seem to disappear. In summary insiders can predict future financial information. Regulation has no effect on insider performance.

Higher managerial ownership is associated with lower equity-based compensation. Similarly lower managerial ownership is associated with higher equity based compensation.

Insiders appear to be able to predict both short-term returns and long-term returns. The results are stronger in purchases compared to sales transactions. 


\subsection{Insider Trading as a Proxy for Information Asymmetry}

There are logical reasons to use insider trading as a proxy for information asymmetry. There are varieties of reasons that motivate an insider to trade in the financial market but some we cannot refuse as they are associated with information asymmetry [32]. Corporate insiders decision to trade may be associated with their superior information, the need for portfolio diversification to reduce risks, and a need for liquidity. While insider selling may be motivated by individuals' need for cash, avoidance of tax, or diversification of an investment portfolio but insider buying is mainly associated with prospects of future terminal cash flows [20]. Insider buying prospects of future terminal value is associated with the confidence about future value of the company which can be motivated by either additional information they have or signalling motives about future prospects of the company but altogether such transaction are motivated by asymmetric information. This study aligns with market microstructure to insider trading performance and trading activities as proxy for information asymmetry [16]. We assume that some insider transactions are informative and hence posed asymmetric information to outside investors [33].

\subsection{Why Corporate Governance?}

As I mentioned above, it appears although most of insiders transactions are essentially legal, few of them are motivated by the degree of information asymmetry between corporate insiders and outside investors [32]. Moreover, insider trading signal is strongly associated with changes in the financial performance of the company in the future [23]. These results suggest that information asymmetry is a key instrument influencing higher opportunistic trading activities from insiders and their subsequent abnormal performance in the capital market $[24,25]$.

Studies into the sources of information asymmetry suggest that the accrual of information, R\&D and analyst following have been strongly associated with the occurrence of opportunistic trading activities by insiders $[16,34,35,50]$. Despite these findings, there are fewer studies investigating the role of corporate policies towards insider trading activities in the capital markets [6,37]. Effective corporate policies are possible with an effective internal governance structure such as sizeable board, more influence of independent board members and separation of two positions of the company (chief executive and chairperson of the board) that are known to enhance corporate disclosure and more information efficiency $[10,17]$.

\subsection{Board Size}

The company boards of directors have legal and fiduciary responsibilities to the company shareholders and are important instrument to protect shareholders interest in the company. The preference in many US Corporation is smaller boards than large board structure as they consume less resources, less bureaucratic and highly effective in terms of decision making [17]. Literature on board size and information disclosure is limited as results suggest mixed evidence associated with information disclosure $[17,37]$. One strand suggest large board size is associated with information disclosure while others argued that large board size is associated with higher stock volatility which implies that higher information asymmetry [7,17]. This implies that large board size has both positive and negative effect to the information disclosure. However, it appears large board size has more diversity and hence they may have better mechanism to monitor insiders in terms of their trading activities. Further large board sizes are associated with more independent directors and therefore enhancing corporate disclosure that will reduce insider performance.

H1a: There is positive relationship between insider trading activities and the number of directors on the board.

H2a: Market reactions following insider transactions are positively associated with the number of directors on the board.

\subsection{Board Independence}

Research has suggested that independent directors play a substantial role in improving disseminating financial reports to the public [7]. The independent directors on the board are regarded as important board monitoring tool against company insiders [17]. The SEC, NYSE and NASDAQ all emphasise that boards should have more independent directors and that they should be given a greater role in preparing financial reports [7]. SOX and the UK Combined Code (1998) both define independent directors, sometimes known as non-executive directors, as directors whose only relationship with the firm is through the directorship. This is aimed at ensuring that independent directors can take independent judgements when considering corporate decisions. Therefore we argued that the more independent directors are included in the board the better board will be in terms of monitoring insider trading activities. Further, the presence of independent directors is strongly associated with enhanced disclosure by the company and this may also be associated with less performance of insiders in the capital market.

$H 1 b$ : The ratio of independent directors in the board is inversely associated with insider trading activities in the capital markets.

H2b: Market reactions following insider transactions decline as the number of independent directors increases.

\subsection{Split}

The independence of the board improves when the top role in the corporation is filled by an independent director [38]. The separation of the role of the chairman and chief executive office is a recommendation in many corporate governance guidelines. Combining the two most powerful positions in a company may create a conflict of interest in decision-making as the function of board will be impair by the presence of a chairman who is also the head of the management of the corporation $[38,39,40]$. Studies have found the separations of the two top positions are strongly 
associated with more corporate disclosure and enhanced monitoring of the board [10,17]. This means split boards will have negative or inversely relationship with insider trading activities and insider performance in the capital market.

H1c: The separation of the chief executive and chairman roles is inversely associated with insider trading activities.

H2c: Market reaction following insider transactions declines when the two roles of chief executive and chairman are separated.

\subsection{Founders}

The presence of the founding board member on the board often causes a conflict of interest between shareholders. The presence of a founding member on the board of directors may affect the level of corporate disclosure to the capital markets as they are associated with less public disclosure due to fair of competition and impairment of their interest. [10,17,30]. Founding members will want less public disclosure if they feel that this might impair their interests and this means that it may offer more opportunity for insiders to trade opportunistically and also enhance insider performance.

H1d: Founding members on the board increase the share price reaction following the transactions of corporate insiders.

H2d: Founding members on the board increase the trading activity of insiders associated with future cash flows.

\subsection{Debt Financing}

Capital structure theory argues that debt financing helps to manage the free cash flows available to the manager $[41,42]$. The introduction of debt into the capital structure imposes a compulsory obligation on managers and limits the financial resources particularly cash flow, which may be spent on personal managerial needs. Excess in cash flows may encourage managers to increase their personal expenditure, undertake risk investment that will increase firm value but at the expense of shareholders capital [41]. The presence of debt in the company contributes to more effective monitoring as debt holders want to ensure that the company continues to pay its debts in the future $[10,22]$. This also implies that there is a negative relationship between debt level and insider trading activities and performance in the capital market.

H1e: There is an inverse relationship between a firm's debt level and insider trading activities.

H2e: There is an inverse relationship between market reaction following insider transactions and the debt level in the firm.

\section{Materials and Methodology}

\subsection{Sample Construction and Data Description}

Insider trading data consists of daily transactions undertaken by insiders in US. Section 16 defines insiders as corporate officers, directors and large shareholders are required to report any transactions they have undertaken to the Security Exchange Commission (SEC). We collected this data from First Call/ Thompson One Financial Insider Filling. The corporate governance data was manually taken from proxy statements provided by Edgar Fillings, a database to which public corporations supply either their annual, or semi-annual reports about their performance to the SEC. The financial data was collected from Thompson Financial for S\&P 500 Index firms. Our initial data for insider trading was 431,895 daily transactions that consist of 171,136 insider purchases and 260,759 insider sales. Cleaning for duplication and noisy transactions we remained with 17,885 that consists of 3,335 insider purchases and 14,550 insider sales. This indicates that the ratio for the sample is 1 insider purchases for every 4 insider sales. We also removed some of insider transactions that we could not find corporate governance data and remained with only 250 firms for S\&P 500 from 2000 to 2005 . This provided us with 1160 observations.

\subsection{Methodology}

I computed insider performance using standard cumulative (average) abnormal returns (using a standard market model) focusing on 41 days centred on the insider transaction day. The standard market model was used by previous studies to determine insider profit in the capital markets $[1,12,13,14]$. The simple market model has been argued by earlier studies to yield better and more accurate abnormal returns than the Capital Asset Pricing Model (see Equation 1) $[12,43,44]$.

I assume a linear relationship between stock returns and market returns. This is adjusted using size and risk factors to control for firm size and risk associated with the firm (see Equation 4).

$$
\begin{gathered}
R_{i t}=\alpha_{i}+\beta_{i} R_{m t}+\ell i t \\
A R_{i t}=R_{i t}-E(R i t) \\
A R_{i t}=R_{i t}-\left(\alpha_{i}+\beta_{i} R_{m t}\right)
\end{gathered}
$$

Where:

Rit = the stock return of firm $i$ at given date $t$

Rmt = the stock return on the market at given date $t$ measured by (S\&P 500 Composite Index)

ARit = the abnormal share price returns for firm $i$ at a given date

$E$ (Rit) $=$ the expected return of firm $i$ at the given date $t$ $\alpha$ and $\beta$ are market parameters obtain through ordinary least square (OLS)regression

Thin trading is ubiquitous in the event study research area, but since this sample consists of large market capitalised firms, this should not be significant. However, [2] simple market model prediction error adjustment was used to adjust the abnormal returns and to control for possible thin trading. The time-varying size effect of [45], [46] and [2] in prediction errors was used to adjust the abnormal returns.

For each month firms were ranked by market capitalisation and sorted into ten equally weighted portfolios. The average return for each portfolio was calculated based on its size. Size and risk-adjusted returns were measured as follows: 


$$
A R_{i t}=R_{i t}-R_{i(p) t}-\left(\alpha_{i}-\alpha_{i(p)}\right)-\left(\beta_{i}-\beta_{i(p)}\right) R_{m t}
$$

Where:

Rpt $=$ size control adjusted returns of a portfolio at given date $t$

apt and $\beta p t$ are market parameters for the portfolio are obtain through OLS regression.

The market parameters for both securities and portfolios were estimated at between 200 days before the transaction date to 20 days before the trading by an insider. Our event period is 41 days around the transactions date (insider transactions date obtained from electronic filing). Earlier studies have used either transaction date, announcement date or both [1]. I focus on the transactions date instead of announcement date [12,23], since although there is a 40 days grace period for an insider to report his/her transactions, some outside investors may obtain the information about insider transactions from other sources before the 40 days period. They will react positively (or negatively) following insider purchase or sales of stocks in the capital markets. It is therefore economically meaningful to consider transactions date rather than reporting date [23].

Abnormal returns were averaged across the event day and across securities in the sample. The test procedure follows the standardised cross-sectional t-test [47]. This standardises the abnormal returns for the given event date using the standard deviation of the abnormal returns during the estimation period.

$$
S A R_{i t}=A R_{i t} / \hat{\sigma}_{i} \sqrt{1+\frac{1}{T_{i}}+\frac{\left(R_{m t}-\bar{R}_{m}\right)^{2}}{\sum_{E=-221}^{-21}\left(R_{m t}-\bar{R}_{m}\right)^{2}}}
$$

Where:

ARit = the abnormal share price returns for firm $i$ at a given date

Rmt = the return on market during estimation period

Rm. = the average return on market during estimation period

Ti= the number of trading days in the estimation period of a stock

$\sigma=$ the standard deviation of size and risk-adjusted abnormal share price return

SARit =standardised abnormal share price returns

The cross-sectional t-test assumes that the cumulative average standardised abnormal return is divided by the standard deviation of estimation period abnormal return. [47] shows that this test is not affected by event-induced variance (this occurs when the variance of abnormal return during the event is greater than the variance of the abnormal return in the estimation period). This variance occurs mainly for smaller firms. Insider trading may cause an increase in the volume of trades, causing an increase in return volatility during the given period. When this happens, the assumption of identical distributed excess returns is violated [48].

I used the absolute value of $\operatorname{CAR}(0,20)$ to measure the magnitude of the reaction following insider transactions, using transaction date as an event. Previous studies considered share price abnormal returns as a proxy for insider profit $[1,2,5,12,14]$. I also conducted a linear regression setting insider purchase trading activities against firm characteristics. The theoretical argument behind such a method is that I anticipated that corporate insiders were associated with certain corporate characteristics, rather than assuming that they occur at random [24]. It is understood in the literature that investors do intend to overreact or under react following the announcement of certain kind of stock as a result of stock market anomalies [24]. Such market anomalies lead us to argue that corporate insiders may also trade differently in stocks with different financial characteristics as a result of investors' different expectations towards them [25].

\subsubsection{Multivariate Analysis}

In my multiple regression analysis, the focus is on CAR $(0,20)$, since it is capable of capturing the complete market reaction following insider transactions. Following earlier studies, we use the absolute value of cumulative abnormal return from the purchase and sale of insider transactions as a dependent variable. An insider purchase has few justifications apart from superior information and future terminal benefits compared to insider sales of stocks [20]. In my cross-sectional regressions I included independent variables such as firm, governance and insider transaction characteristics.

My proxy for measuring opportunistic insider trading activities is the purchase ratio measuring the amount of insider trading activity associated with future cash flows against total insider trading activities. The market timing theory argues that insiders time their transactions perfectly in the capital markets. When insider trades are motivated by private information and it is understood that the market overreacts towards market prices, this offers an opportunity for opportunistic trades to take advantage of market mispricing errors [24]. This implies that for certain firms with certain characteristics it is expected that insiders will trade differently compared to other firms.

I consider purchase transactions to be opportunistic for the following reasons. Firstly, purchase transactions decisions by insiders are mainly associated with future financial benefit rather than liquidity needs [20]. Secondly, insider purchase transactions are associated more with corporation discretional disclosure than insider sales transactions [49]. Some corporate insiders (particularly company executives) tend to disclose more bad news instead of good news before they purchase stocks but they do not alter news before they sell stocks [49]. Thirdly, these transactions are exposed to lower litigation risks compared to insider selling transactions [32]. We adopted the methodology of [24] and [25] to examine if insider purchasing of stocks occur at random or are closely associated with certain firm characteristics. I used an OLS regression to examine if insider trading activities are associated with firm characteristics.

\section{Results and Discussion}

Table 2 provides a statistical summary of the insider trading sample. The results are similar to those of previous insider trading research as insider sales were more than insider purchases. In fact insider selling tends to increase 
with increase in the size of the firm $[19,12]$. Our sample consists of 250 largest industrial firms listed in S\&P 500 Index and found the sample construe of 1 insider purchase and 4 insider sales. This concurs with prior researches that sales to purchase ratio increase with the increase in the size of the firm $[15,23,25,50]$. This could be mainly due to the compensation arrangement some insiders received in their employment contract. Table 3 presents the corporate governance data for 250 firms from 2000 to 2005. Our sample has an average 10 to 11 directors inside the boardroom. $84 \%$ of the boards in the sample have nonexecutive directors while $70 \%$ combined the top position of chief executives and chairperson of the boards. This description is similar to the previous studies.

Table 2. Summary statistics of insider trading from 2000-2005

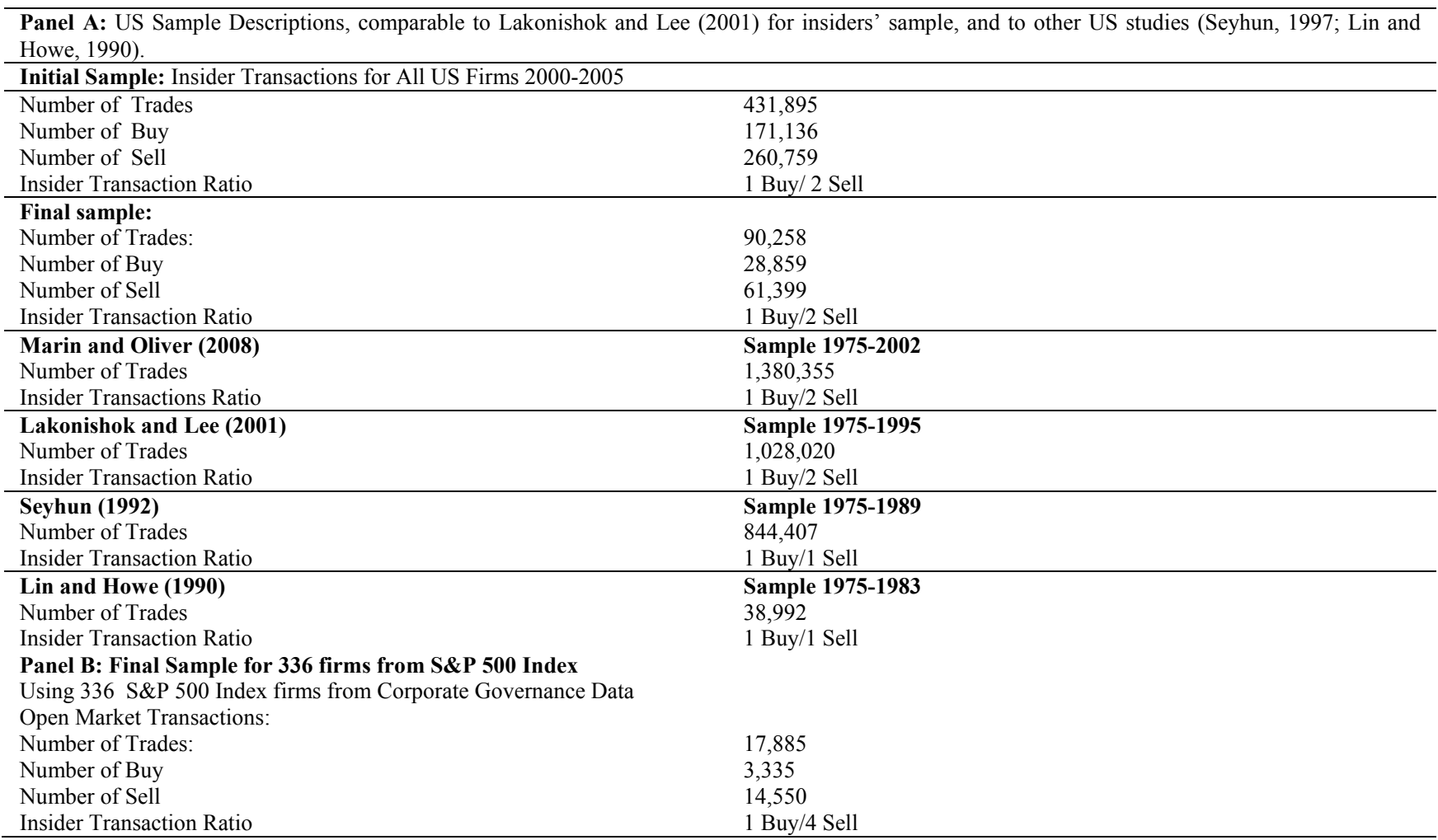

This table shows the summary statistics for all insiders' transactions. I compared them with previous studies in terms of number of buy and sells by corporate insiders in the capital market.

Table 3. Summary statistics of corporate governance data

\begin{tabular}{|c|c|c|c|c|c|c|}
\hline \multicolumn{7}{|l|}{ Panel C: } \\
\hline Variable & $\mathbf{N}$ & Mean & Median & Std & Min & Max \\
\hline \multicolumn{7}{|l|}{ Board Characteristics } \\
\hline Board size & 1160 & 10.65 & 11.00 & 2.37 & 5.00 & 20.00 \\
\hline Board independence (\%) & 1160 & 0.83 & 0.85 & 0.09 & 0.40 & 1.00 \\
\hline Duality & 1160 & 0.71 & 1.00 & 0.46 & 0.00 & 1.00 \\
\hline \multicolumn{7}{|l|}{ Directors' Characteristics } \\
\hline Founder ratio & 1160 & 0.11 & 0.00 & 0.31 & 0.00 & 1.00 \\
\hline Profession $(\%)$ & 1160 & 0.20 & 0.18 & 0.13 & 0.00 & 0.70 \\
\hline Gender (\%) & 1160 & 0.12 & 0.11 & 0.09 & 0.00 & 0.55 \\
\hline Director age & 1160 & 59.75 & 60.00 & 3.22 & 45.29 & 71.57 \\
\hline Tenure & 1160 & 8.51 & 8.09 & 3.66 & 0.50 & 26.17 \\
\hline \multicolumn{7}{|l|}{ Firm Characteristics } \\
\hline Market capitalization ('\$Bill) & 1160 & 20.24 & 8.64 & 38.84 & 0.44 & 476.12 \\
\hline Gearing ratio & 160 & 0.20 & 0.20 & 0.14 & 0.00 & 0.65 \\
\hline Debt ratio & 1160 & 0.25 & 0.24 & 0.16 & 0.00 & 0.67 \\
\hline Return on assets $(\%)$ & 1160 & 7.13 & 7.15 & 6.49 & -34.19 & 25.28 \\
\hline Total assets ('\$Bill) & 1160 & 17.60 & 7.38 & 41.61 & 0.24 & 495.02 \\
\hline Sales (‘\$Bill) & 1160 & 13.34 & 6.23 & 23.48 & 0.13 & 193.52 \\
\hline Book to market ratio & 1160 & 0.39 & 0.33 & 0.30 & -0.03 & 4.81 \\
\hline Return on equity (\%) & 1160 & 15.19 & 14.59 & 24.86 & -152.77 & 235.11 \\
\hline
\end{tabular}

The table shows the summary statistics of the board characteristics of a sample of 250 companies from 2000-2005. The board size is defined as the number of directors in the board. Board Independence is defined as ratio of non-executive directors in the board structure. Duality is defined as combined role of Chief Executive Officer and Chairman of the Board roles. Founder is the founder of the company as well as director of the company. Profession is the ratio of professionals in accounting directors in the board structure. Gender is the ratio of female directors inside the board of directors. Director age is the average director age in the firm. Tenure is the average number of years a board member stays in the board structure. Market capitalization is year-end market capitalization of the firm. Gearing is ratio between firm long-term debt and total assets. Debt ratio is the ratio between firm total debts to firm total assets. Return on assets is the return on assets defined by Thompson Financial. Return on equity is defined as total return on equity. Total assets are firm total assets at the year-end. Sales are firm year total sales. Book-to-market is ratio between firm year end market capitalizations against book value of equity. 
Table 4. Correlation matrices

\begin{tabular}{|c|c|c|c|c|c|c|c|c|c|c|c|c|}
\hline & Lbdsize & lbdind & CEOCHRM & lgender & Found & ldirage & ltenure & 1sales & BVMV & ROE & Debtratio & Size \\
\hline Lbdsize & 1 & & & & & & & & & & & \\
\hline Lbdind & $0.25608^{* * *}$ & 1 & & & & & & & & & & \\
\hline CEOCHRM & -0.02048 & $0.20672 * * *$ & 1 & & & & & & & & & \\
\hline Lgender & $-0.18747 * * *$ & -0.01648 & 0.03034 & 1 & & & & & & & & \\
\hline Found & $-0.17277 * * *$ & $-0.23186^{* * * *}$ & $-0.15094 * * *$ & 0.01213 & 1 & & & & & & & \\
\hline Ldirage & $0.09118^{* * *}$ & 0.0415 & $0.11914 * * *$ & $-0.0985^{* * *}$ & $-0.05593 * * *$ & 1 & & & & & & \\
\hline Ltenure & $-0.06018^{* *}$ & $-0.24747 * * *$ & $-0.0586^{* *}$ & $-0.0906^{* * *}$ & $0.2265 * * *$ & $0.2558 * * *$ & 1 & & & & & \\
\hline Lsales & $0.44643 * * *$ & $0.22465 * * *$ & $0.09225 * * *$ & $0.07123^{* *}$ & $-0.05976^{* *}$ & $0.09308 * * *$ & -0.03875 & 1 & & & & \\
\hline BVMV & $0.07382 * *$ & 0.04568 & $0.07423^{* *}$ & $-0.10653 * * *$ & $-0.04989 *$ & $0.09545 * * *$ & $-0.06635^{* *}$ & $0.05569 * *$ & 1 & & & \\
\hline ROE & 0.03208 & 0.03059 & 0.00451 & $0.16171 * * *$ & -0.02311 & -0.02847 & 0.01802 & $0.04913 *$ & $-0.42446^{* * *}$ & 1 & & \\
\hline Debtratio & $0.26907 * * *$ & $0.14486 * * *$ & $0.10526 * * *$ & $-0.09048 * * *$ & $-0.21101 * * *$ & $0.11262 * * *$ & $-0.07712 * * *$ & $0.15566 * * *$ & $0.1818^{* * *}$ & $0.05342 *$ & 1 & \\
\hline Size & $0.28248 * * *$ & $0.11918 * * *$ & -0.04032 & $0.11403 * * *$ & $0.10664 * * *$ & $0.08625 * * *$ & 0.05399 & $0.635 * * *$ & $-0.37882 * * *$ & $0.18678 * *$ & $-0.15597 * * *$ & 1 \\
\hline
\end{tabular}

This table reports the Pearson correlation matrices for independent variables in. Panels $\mathrm{C}$ respectively. $*, * *$ and $* * *$ denote significance at $10 \%$, $5 \%$ and $1 \%$ levels, respectively. Lbdsize, Lbdind, Lgender, Ldirage, Ltenure, Lsales are defined as natural logarithm of board size, board independence, gender diversity, director age, board tenure and corporate sales. I define board size as the number of board members in the board room, board independent is the ratio of independent directors compare to board size, gender diversity is the ratio of female directors inside the board room. Director age is defined as the as the average age of directors in the board room. Tenure is also defined as the average period a director stays in the board room. Other variables such CEOCHRM (Duality) is defined as combination of two top position of the company, Debt ratio is defined as the ratio of total company debt against firm total assets. Size is defined as natural logarithm of market capitalization at the year end. BKMV is defined as the ratio of book value of equity (total common equity at the yearend) against market value of the firm measured by market capitalization at the end of the year.

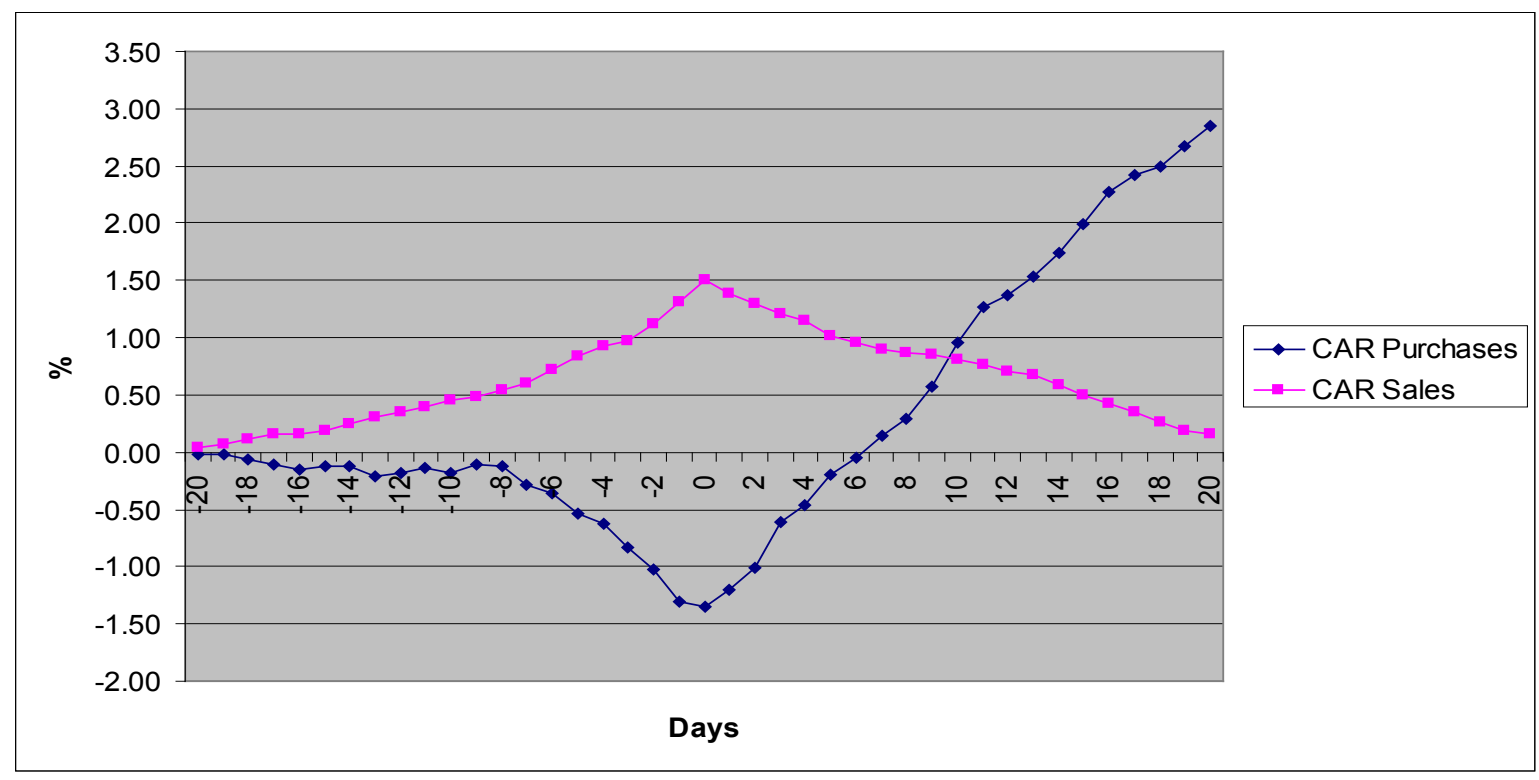

The figure shows the cumulative average abnormal return (CAR) for the insider purchase and sales of stocks. \% is the percentage of change in share price following the sale (purchase) of stocks. Days are the number of days following the transactions of an insider.

Figure 1. Cumulative average abnormal return for buy and sales transactions by insiders (Source: Thompson Financial)

The correlation matrices (see Table 4) reveal that most variables are highly correlated to each other. Most of the variables are similar to the previous studies for example board independence is significant and positively related to the size of the board. One possible explanation is that the introduction of independent directors increases the size of the board [51]. Figure 1 shows the stock response immediately following trading by an insider. It appears that the magnitude of the reaction is positive after the purchase of stock and negative following the sale of stock by an insider. This is consistent with prior literature, I found that the magnitude of the reaction to purchase transactions is $4.1 \%$, and is $-1.2 \%$ for the sale transactions (see also Table 5). This is consistent with other studies that found, for example, in Germany the magnitude of the reaction is $3.60 \%$ for purchase and $-3.54 \%$ for sales; for the UK $\operatorname{CAR}(0,20)$ was around $1.96 \%$ for the purchases and $-1.46 \%$ for sales transactions; and for US [12] found CAR for purchase and sales to be $1.1 \%$ and $-0.9 \%$ respectively. Figure 2 shows the insider trading activities before and after earnings announcement period. I used the earnings announcement dates provided by IBES (Institute of Brokers Estimation Systems). The trading behaviour has not changed despite the introduction of additional fines, monitoring and restrictions. This means either most of insider transactions are perfectly legal and regulators have no issue of concern or they have been more opportunistic in terms of timing their decision to trade in the market.

This can be compared with insider performance as market reactions has also not change if you compare with previous studies. Market reactions following an insider 
transaction occur immediately after the date of the transaction undertaken by an insider. Average Abnormal Return shows that, on average, significant abnormal return is a positive $0.15 \%$ following insider purchase transactions, and a significant negative abnormal return of $0.11 \%$ following insider sales of stocks. Such results confirm that even after SOX's rigorous transformation of corporate leadership and financial disclosures, there are significant abnormal returns following insider transactions. Hence, the first question of this paper relating to the magnitude of reaction after SOX is answered by these results. The market still considers an insider-trading signal to be an important signal for stock investment. Therefore, we can conclude despite these laws the abnormal performance of insiders and opportunistic insider trading activities continued as it was before the new rules.

Table 5 shows that the market reaction following trading of insiders started immediately after the insider decision to trade. I separated the two trading decision to examine if stock investors reacted differently for insider purchases and sales of stock in the capital markets. Consistent with prior research I found that market reactions following insider purchase (sales) are positive (negative), showing that stock markets have at best semistrong market efficiency [5]. I also found that the market reaction following insider sales of stock is lower than that of insider purchases of stocks, showing that investors digest the information from news of insider sales and may consider a variety of reasons from insider trading before following the direction of insider investment decisions.

Sell Transactions Before and After Earnings Announcements

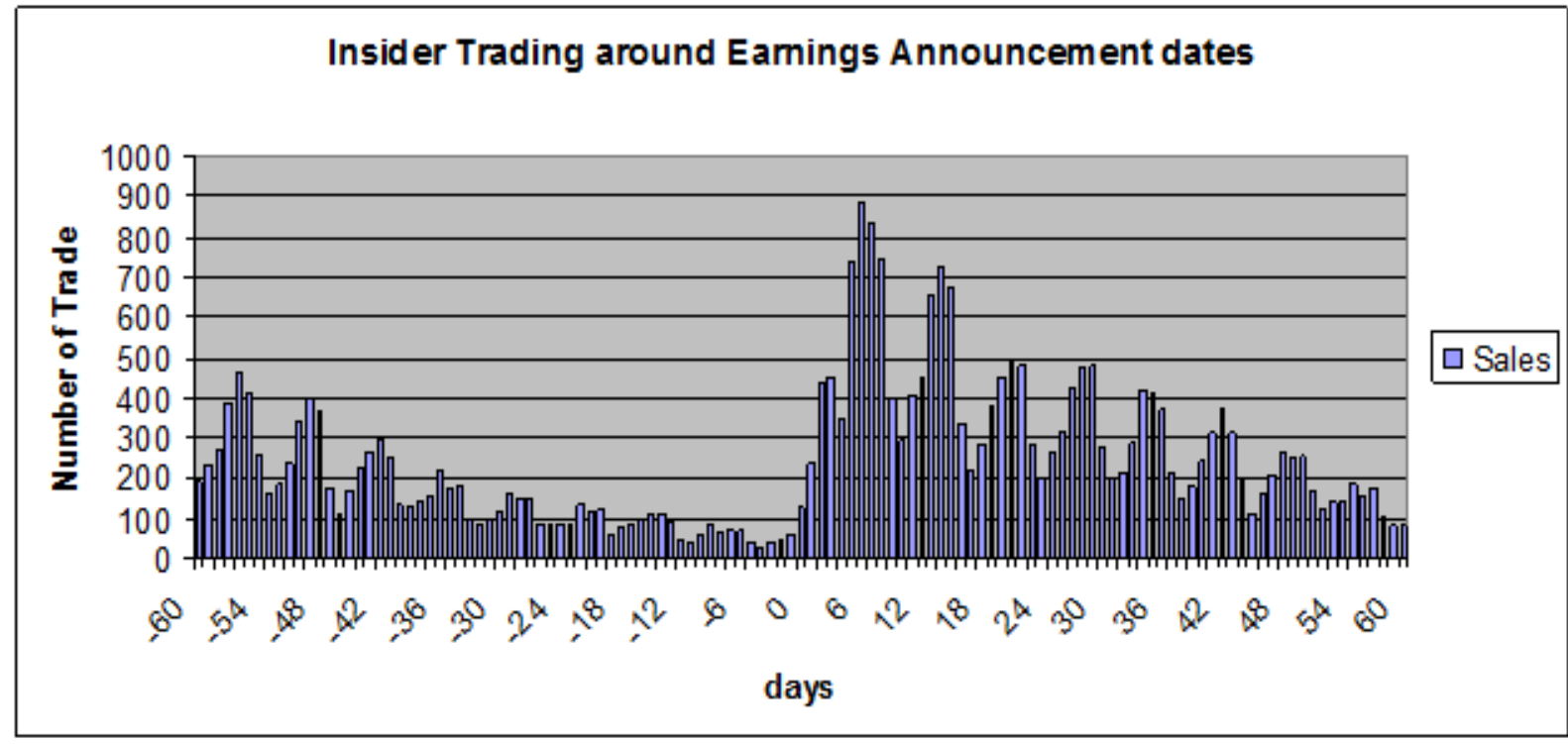

Buy Transactions Before and After Earnings Announcements:

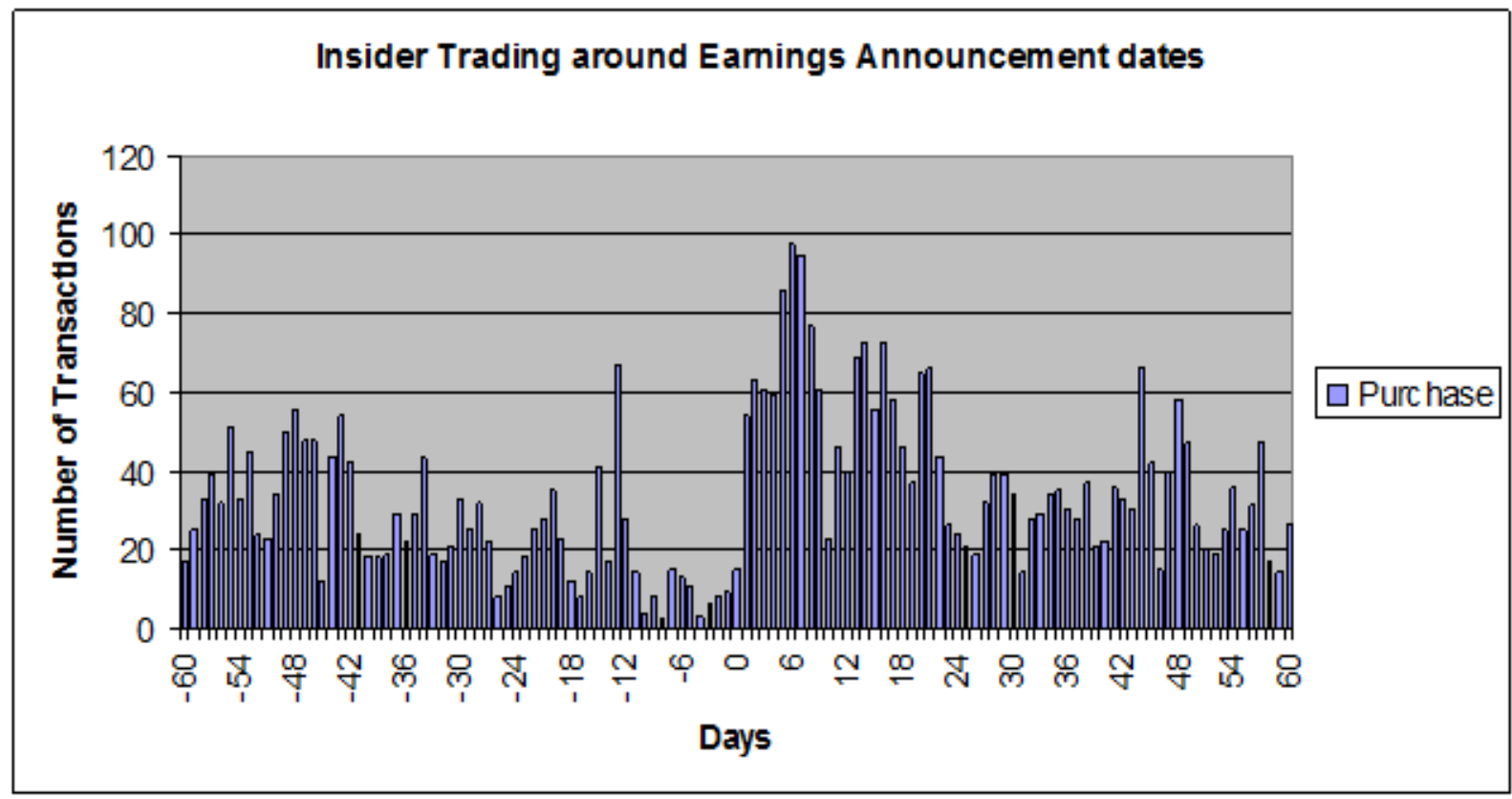

The figure shows volume of the transactions before corporate earnings announcements. I use IBES quarterly earnings announcements and I measure the volume of transactions before and after the corporate earnings announcements from 2000-2005.

Figure 2. Insider trading distribution before and after earnings announcements (Source: Thompson Financial and IBES (Institutional Brokers Estimation System)) 
Table 5. Abnormal returns and significance test (Purchase and sales transactions)

\begin{tabular}{|c|c|c|c|c|c|c|c|c|c|c|c|c|c|c|c|c|c|c|c|}
\hline \multicolumn{10}{|c|}{ Purchase } & \multicolumn{10}{|c|}{ Sales } \\
\hline eventper & $\%$ AAR & StRi & $\%+\mathrm{R}$ & tcs & tbmp & tsign & CAAR & tcumm & $\% \mathrm{CAR}$ & eventper & $\%$ AAR & StRi & $\%+R$ & tcs & tbmp & tsign & CAAR & tcumm & $\%$ CAR \\
\hline-20 & -0.021 & -0.02 & 0.49 & -0.46 & -0.64 & -0.80 & 0.00 & -0.64 & -0.02 & -20 & 0.037 & 0.01 & 0.49 & 1.87 & 1.48 & -1.19 & 0.00 & 1.48 & 0.04 \\
\hline-19 & -0.005 & 0.01 & 0.51 & -0.09 & 0.38 & 0.74 & 0.00 & -0.26 & -0.03 & -19 & 0.035 & 0.02 & 0.49 & 1.53 & 2.19 & -1.90 & 0.00 & 3.67 & 0.07 \\
\hline-18 & -0.036 & -0.02 & 0.50 & -0.70 & -1.03 & 0.27 & 0.00 & -1.29 & -0.06 & -18 & 0.041 & 0.02 & 0.49 & 1.83 & 1.68 & -1.19 & 0.00 & 5.35 & 0.11 \\
\hline-17 & -0.049 & -0.04 & 0.49 & -0.97 & -1.75 & -0.66 & 0.00 & -3.03 & -0.11 & -17 & 0.043 & 0.02 & 0.49 & 1.83 & 1.78 & -0.98 & 0.00 & 7.13 & 0.16 \\
\hline-16 & -0.035 & -0.03 & 0.50 & -0.61 & -1.08 & -0.33 & 0.00 & -4.12 & -0.15 & -16 & -0.004 & 0.01 & 0.49 & -0.18 & 0.61 & -2.41 & 0.00 & 7.74 & 0.15 \\
\hline-15 & 0.020 & 0.00 & 0.50 & 0.43 & 0.03 & -0.20 & 0.00 & -4.08 & -0.13 & -15 & 0.034 & 0.01 & 0.49 & 1.67 & 1.32 & -2.28 & 0.00 & 9.06 & 0.19 \\
\hline-14 & 0.003 & -0.01 & 0.50 & -0.07 & -0.45 & 0.39 & 0.00 & -4.53 & -0.13 & -14 & 0.059 & 0.02 & 0.49 & 3.26 & 2.57 & -1.71 & 0.00 & 11.63 & 0.24 \\
\hline-13 & -0.075 & -0.06 & 0.48 & -1.41 & -2.77 & -1.58 & 0.00 & -7.30 & -0.20 & -13 & 0.069 & 0.03 & 0.50 & 3.31 & 2.71 & -0.88 & 0.00 & 14.34 & 0.31 \\
\hline-12 & 0.029 & 0.01 & 0.50 & 0.51 & 0.43 & 0.16 & 0.00 & -6.87 & -0.18 & -12 & 0.045 & 0.02 & 0.49 & 1.94 & 1.33 & -1.19 & 0.00 & 15.67 & 0.36 \\
\hline-11 & 0.035 & -0.01 & 0.50 & 0.62 & -0.59 & 0.40 & 0.00 & -7.46 & -0.14 & -11 & 0.037 & 0.01 & 0.49 & 1.67 & 1.12 & -2.72 & 0.00 & 16.79 & 0.40 \\
\hline-10 & -0.038 & -0.03 & 0.49 & -0.67 & -1.28 & -1.00 & 0.00 & -8.74 & -0.18 & -10 & 0.062 & 0.03 & 0.50 & 2.79 & 2.67 & -0.14 & 0.00 & 19.46 & 0.46 \\
\hline-9 & 0.066 & 0.00 & 0.50 & 1.13 & 0.02 & -0.22 & 0.00 & -8.72 & -0.11 & -9 & 0.033 & 0.02 & 0.50 & 1.41 & 1.73 & -0.84 & 0.00 & 21.19 & 0.49 \\
\hline-8 & -0.010 & -0.04 & 0.49 & -0.19 & -1.58 & -1.23 & 0.00 & -10.30 & -0.12 & -8 & 0.050 & 0.02 & 0.49 & 2.52 & 1.93 & -3.09 & 0.01 & 23.12 & 0.54 \\
\hline-7 & -0.164 & -0.08 & 0.47 & -3.43 & -4.02 & -3.14 & 0.00 & -14.32 & -0.29 & -7 & 0.057 & 0.02 & 0.49 & 3.27 & 2.49 & -2.59 & 0.01 & 25.61 & 0.60 \\
\hline-6 & -0.071 & -0.05 & 0.49 & -1.28 & -2.04 & -1.38 & 0.00 & -16.36 & -0.36 & -6 & 0.130 & 0.06 & 0.51 & 6.39 & 6.05 & 1.26 & 0.01 & 31.66 & 0.73 \\
\hline-5 & -0.176 & -0.08 & 0.49 & -2.68 & -2.39 & -0.46 & -0.01 & -18.75 & -0.53 & -5 & 0.110 & 0.05 & 0.50 & 4.85 & 4.25 & 0.41 & 0.01 & 35.91 & 0.84 \\
\hline-4 & -0.099 & -0.04 & 0.50 & -1.54 & -1.40 & -0.22 & -0.01 & -20.15 & -0.63 & -4 & 0.090 & 0.05 & 0.49 & 4.11 & 4.46 & -1.16 & 0.01 & 40.37 & 0.93 \\
\hline-3 & -0.199 & -0.10 & 0.47 & -3.24 & -3.32 & -2.84 & -0.01 & -23.48 & -0.83 & -3 & 0.047 & 0.02 & 0.48 & 2.18 & 1.69 & -2.78 & 0.01 & 42.06 & 0.97 \\
\hline-2 & -0.200 & -0.11 & 0.48 & -3.09 & -3.48 & -1.74 & -0.01 & -26.95 & -1.03 & -2 & 0.140 & 0.07 & 0.51 & 6.17 & 6.55 & 1.72 & 0.01 & 48.61 & 1.11 \\
\hline-1 & -0.269 & -0.15 & 0.48 & -4.49 & -5.33 & -1.94 & -0.01 & -32.29 & -1.30 & -1 & 0.201 & 0.09 & 0.53 & 10.50 & 10.15 & 5.34 & 0.01 & 58.77 & 1.32 \\
\hline 0 & -0.046 & -0.01 & 0.50 & -0.93 & -0.58 & 0.05 & -0.01 & -32.87 & -1.34 & 0 & 0.191 & 0.08 & 0.52 & 11.00 & 10.07 & 5.91 & 0.02 & 68.83 & 1.51 \\
\hline 1 & 0.146 & 0.08 & 0.57 & 3.19 & 3.53 & 7.54 & -0.01 & -29.33 & -1.20 & 1 & -0.114 & -0.06 & 0.46 & -6.38 & -7.09 & -9.20 & 0.01 & 61.75 & 1.39 \\
\hline 2 & 0.194 & 0.06 & 0.52 & 3.40 & 2.56 & 1.39 & -0.01 & -26.78 & -1.01 & 2 & -0.099 & -0.06 & 0.46 & -4.98 & -6.39 & -7.64 & 0.01 & 55.36 & 1.29 \\
\hline 3 & 0.391 & 0.16 & 0.60 & 8.22 & 7.79 & 9.17 & -0.01 & -18.99 & -0.61 & 3 & -0.079 & -0.04 & 0.46 & -4.09 & -4.54 & -8.00 & 0.01 & 50.82 & 1.21 \\
\hline 4 & 0.148 & 0.08 & 0.52 & 2.69 & 3.30 & 1.84 & 0.00 & -15.69 & -0.47 & 4 & -0.067 & -0.02 & 0.48 & -3.17 & -2.46 & -4.52 & 0.01 & 48.36 & 1.15 \\
\hline 5 & 0.269 & 0.11 & 0.55 & 5.02 & 4.55 & 4.23 & 0.00 & -11.14 & -0.20 & 5 & -0.128 & -0.05 & 0.46 & -6.09 & -4.94 & -7.07 & 0.01 & 43.42 & 1.02 \\
\hline 6 & 0.155 & 0.07 & 0.51 & 3.33 & 3.30 & 1.11 & 0.00 & -7.84 & -0.04 & 6 & -0.062 & -0.03 & 0.47 & -3.36 & -3.03 & -5.38 & 0.01 & 40.39 & 0.96 \\
\hline 7 & 0.184 & 0.08 & 0.53 & 4.61 & 4.53 & 3.66 & 0.00 & -3.31 & 0.14 & 7 & -0.064 & -0.03 & 0.47 & -3.98 & -4.10 & -7.59 & 0.01 & 36.29 & 0.89 \\
\hline 8 & 0.153 & 0.07 & 0.56 & 3.45 & 3.60 & 6.03 & 0.00 & 0.29 & 0.29 & 8 & -0.028 & -0.02 & 0.47 & -1.59 & -2.20 & -7.20 & 0.01 & 34.09 & 0.87 \\
\hline 9 & 0.274 & 0.11 & 0.57 & 5.54 & 5.07 & 6.16 & 0.01 & 5.36 & 0.57 & 9 & -0.013 & -0.03 & 0.45 & -0.70 & -3.71 & -10.45 & 0.01 & 30.38 & 0.85 \\
\hline 10 & 0.387 & 0.13 & 0.55 & 8.41 & 6.61 & 4.85 & 0.01 & 11.97 & 0.96 & 10 & -0.041 & -0.03 & 0.45 & -2.08 & -3.77 & -10.07 & 0.01 & 26.61 & 0.81 \\
\hline 11 & 0.319 & 0.13 & 0.56 & 6.77 & 6.17 & 6.08 & 0.01 & 18.14 & 1.27 & 11 & -0.054 & -0.03 & 0.48 & -2.62 & -3.44 & -3.39 & 0.01 & 23.17 & 0.76 \\
\hline 12 & 0.095 & 0.04 & 0.49 & 1.73 & 1.90 & -0.47 & 0.01 & 20.04 & 1.37 & 12 & -0.055 & -0.01 & 0.49 & -2.53 & -1.26 & -2.21 & 0.01 & 21.91 & 0.70 \\
\hline 13 & 0.164 & 0.04 & 0.50 & 3.38 & 1.69 & 0.47 & 0.02 & 21.73 & 1.53 & 13 & 0.029 & -0.01 & 0.48 & -1.48 & -1.00 & -4.60 & 0.01 & 20.91 & 0.67 \\
\hline 14 & 0.203 & 0.09 & 0.54 & 5.42 & 5.54 & 4.36 & 0.02 & 27.27 & 1.74 & 14 & -0.091 & -0.05 & 0.45 & -5.77 & -6.77 & -12.41 & 0.01 & 14.14 & 0.58 \\
\hline 15 & 0.258 & 0.09 & 0.54 & 5.52 & 4.39 & 3.74 & 0.02 & 31.66 & 1.99 & 15 & -0.080 & -0.05 & 0.47 & -4.50 & -5.94 & -6.59 & 0.01 & 8.19 & 0.50 \\
\hline 16 & 0.276 & 0.12 & 0.56 & 5.66 & 4.76 & 5.64 & 0.02 & 36.42 & 2.27 & 16 & -0.084 & -0.06 & 0.43 & -4.14 & -6.46 & -12.67 & 0.00 & 1.74 & 0.42 \\
\hline 17 & 0.156 & 0.06 & 0.47 & 3.07 & 2.68 & -2.87 & 0.02 & 39.11 & 2.43 & 17 & -0.062 & -0.05 & 0.43 & -3.33 & -5.34 & -14.78 & 0.00 & -3.60 & 0.36 \\
\hline 18 & 0.075 & 0.07 & 0.53 & 10.03 & 20.75 & 13.09 & 0.03 & 59.86 & 2.50 & 18 & -0.097 & -0.06 & 0.45 & -32.05 & -37.28 & -58.68 & 0.00 & -40.88 & 0.26 \\
\hline 19 & 0.169 & 0.08 & 0.51 & 3.05 & 3.37 & 0.93 & 0.03 & 63.23 & 2.67 & 19 & -0.077 & -0.02 & 0.48 & -3.16 & -1.89 & -2.91 & 0.00 & -42.77 & 0.18 \\
\hline 20 & 0.176 & 0.04 & 0.49 & 39.05 & 22.71 & -9.11 & 0.03 & 85.94 & 2.85 & 20 & -0.022 & -0.01 & 0.48 & -12.56 & -15.75 & -35.78 & 0.00 & -58.52 & 0.16 \\
\hline
\end{tabular}

The table provides a list of average abnormal returns computed using market model. The $\beta$ 's and $\alpha$ are estimated using (-221,-21)-day window, the returns coverall the insider transactions of the sample. Brown and Warner (1983) and Patell (1976) defined T as a test represents the cross sectional $t$ test. Tbmp is defined as Standardised Cross-Sectional test adopted by the Boehmer.et al (1991). The rank and sign test are non-parametric test used to determine the normality of the distribution of the abnormal returns. AAR represents average abnormal returns. StRi is defined as Standardised Average Abnormal Returns. \%+Returns are defined as the percentage of positive abnormal returns in the sample. CAR is defined as the Cumulative average abnormal returns. Tcumm is defined as cumulative standardised t-test.

CAR shows that following insider purchase was significant at $0.3 \%$ positive two days following the date of insider purchasing of stock. This shows that share prices started to appreciate immediately following the insider decision to purchase stocks. This is evidence to suggest that investors consider the news about purchase of stock as good news and they start to have an optimistic view of corporate performance [12]. Similarly for sales of stock I found that share prices started to decline by $-0.02 \%$ two days after the date insiders sold stocks. This is evidence that investors are pessimistic following the news of selling of stocks by insiders.
The results in the Table 5 concur with one of the motivations of this paper to examine whether or not US capital market reactions changed following the introduction of rules regarding insider trading has not changed their behaviour and performance in the market.. I found that market reactions are significant positive (negative) following insider purchase (sales) of stocks in the capital markets. Similar trend continued throughout the entire period of my sample from 2000 to 2005 (see Table 10). This raises concerns about the effectiveness of the Act in increasing transparency and in improving market efficiencies. Further, I found that the reaction 
following insider sales of stock is smaller than for the insider purchasing of stock (see Table 5).

I also showed in Figure 1 that the trend of share price is positive (negative) following insider purchase (sale) of stocks. My result is similar to findings by $[12,14]$. My findings on the timing of insiders around earnings announcement news are similar to those of previous studies by [12]. My findings on insider trading activities against earnings announcement are similar to prior studies suggesting that one of the reasons for such a decline is as result of discouragement by the SEC and because some corporations prevent insiders from trading before corporate earnings news [15]. Further, fear of legal investigation by insiders prompted a decline in the trading trend before corporate news. Following corporate earnings news such trading activities increased substantially to 60 days. This helps to answer our first interest that the regulation had not been effective despite several improvements.

The results in Table 6 support Hypothesis 2, that good corporate governance mitigates information asymmetry between corporate insiders and outside investors. I found, consistent with our hypothesis, that good governance is determined by small boards: one that are highly independent and closely monitored by debt holders have fewer market reactions than in large board size, one with fewer independent directors and lower debt level corporations. I also found in Table 6 that multiple trading increases the importance of information signals from insider purchasing of stocks. This may be as a result of the belief that the higher the frequency of insiders trading stock, the more the importance of insider trading signal $[33,52]$. Information asymmetry theory stipulates that multiple transactions encourage investor optimism towards information from insider trading activities $[1,33]$.

I also examined market reactions following insider sales of stock. In Table 7 my results show that small, highly independent boards, with a higher presence of debt, reduce market reactions following insider sales of stock in the capital markets. In examining multiple trading transactions, our results in Table 7 also reveal that market reactions decline when insider sells stocks frequently. This can be supported by the litigation risk hypothesis that an increase in insider trading activities reduces investors' optimism that the trading may be motivated by non-public information $[1,5,12,23]$. I also found that market reactions were negatively associated with debt level. This is similar to [5]: I can elaborate that perhaps close monitoring by debt holders increases the level of transparency, which subsequently improves market efficiency.

Table 6. Cross-sectional Regression Model for Insider Purchase Relative to Trading Day

CARit $=\alpha i t+\beta 1$ bdsize $+\beta 2$ bdind $+\beta 3$ CEOCHRM $+\beta 6$ FOUND $+\beta 7$ multiple trade $+\beta 8$ tsize $+\beta 9$ Size $+\beta 10$ BooktoMarket $+\beta 11$ ROE $+\beta 12$ Debt-equity ratio + eit

\begin{tabular}{|c|c|c|c|c|c|c|c|c|c|c|c|c|}
\hline \multirow[b]{2}{*}{ Variable } & \multicolumn{3}{|c|}{$\operatorname{CAR}(0,20)$} & \multicolumn{3}{|c|}{$\operatorname{CAR}(0,5)$} & \multicolumn{3}{|c|}{$\operatorname{CAR}(0,1)$} & \multicolumn{3}{|c|}{$\operatorname{CAR}(0,20)>0.001$} \\
\hline & Coeff & SE & T-value & Coeff & SE & T-value & Coeff & SE & T-value & Coeff & SE & T-value \\
\hline \multicolumn{13}{|l|}{ Director Identity: } \\
\hline Chairman & 0.016 & 0.016 & 1.02 & 0.008 & 0.015 & 0.51 & 0.002 & 0.006 & 0.36 & -0.013 & 0.029 & -0.45 \\
\hline \multicolumn{13}{|l|}{ Board Structure: } \\
\hline BoardInd & -0.185 & 0.025 & $-7.47 * * *$ & -0.132 & 0.016 & $-8.02 * * *$ & -0.050 & 0.009 & $-5.69 * * *$ & -0.274 & 0.040 & $-6.86 * * *$ \\
\hline Bdsize & 0.013 & 0.005 & $2.86 * * *$ & 0.009 & 0.003 & $2.77 * * *$ & 0.008 & 0.002 & $3.85 * * *$ & 0.021 & 0.010 & $2.06 * *$ \\
\hline FOUND & 0.005 & 0.006 & 0.85 & 0.007 & 0.004 & $1.86^{* *}$ & -0.003 & 0.002 & -1.33 & 0.015 & 0.013 & 1.15 \\
\hline Dual & -0.009 & 0.004 & $-2.11 * *$ & 0.001 & 0.003 & 0.21 & -0.001 & 0.001 & -0.79 & -0.014 & 0.008 & $-1.83^{*}$ \\
\hline \multicolumn{13}{|l|}{ Control Variables: } \\
\hline Multiple Transactions & 0.021 & 0.005 & $3.87 * * *$ & 0.019 & 0.004 & $5.15 * * *$ & 0.008 & 0.002 & $3.78 * * *$ & 0.026 & 0.010 & $2.66 * * *$ \\
\hline Transaction size & -0.001 & 0.201 & 0.00 & 0.049 & 0.085 & 0.57 & 0.018 & 0.036 & 0.51 & 0.037 & 0.237 & 0.15 \\
\hline Size & -0.007 & 0.002 & $-4.29 * * *$ & -0.004 & 0.001 & $-3.77 * * *$ & -0.002 & 0.001 & $-3.5 * * *$ & -0.009 & 0.005 & $-1.99 * *$ \\
\hline $\mathrm{BM}$ & -0.001 & 0.007 & -0.10 & -0.004 & 0.004 & -0.99 & -0.003 & 0.004 & -0.68 & 0.009 & 0.009 & 0.92 \\
\hline ROE & -0.004 & 0.005 & -0.77 & -0.007 & 0.004 & $-1.9 *$ & -0.002 & 0.003 & -0.74 & 0.007 & 0.012 & 0.58 \\
\hline Leverage & -0.030 & 0.011 & $-2.66 * * *$ & -0.007 & 0.008 & -0.84 & -0.018 & 0.005 & $-3.67 * * *$ & -0.020 & 0.021 & -0.95 \\
\hline Constant & 0.280 & 0.030 & $9.29 * * *$ & 0.181 & 0.020 & $9.05 * * *$ & 0.087 & 0.011 & $7.91 * * *$ & 0.388 & 0.060 & $6.43 * * *$ \\
\hline Industry & Yes & & & Yes & & & Yes & & & Yes & & \\
\hline Time & Yes & & & Yes & & & Yes & & & Yes & & \\
\hline R-Sqr & 0.288 & & & 0.221 & & & 0.117 & & & 0.416 & & \\
\hline Adj-Rsq & 0.281 & & & 0.213 & & & 0.108 & & & 0.397 & & \\
\hline F-test & $39.44 * * *$ & & & $27.62 * * *$ & & & $12.86 * * *$ & & & $21.95 * * *$ & & \\
\hline $\mathrm{N}$ & 1577 & & & 1570 & & & 1564 & & & 573 & & \\
\hline
\end{tabular}

$*, * *$ and $* * *$ denote significance at $10 \%, 5 \%$ and $1 \%$ levels, respectively.

The table shows the relationship between board structure and CAR $(0,20)$. CAR $(0,20)$ is from market model size and risk adjusted abnormal returns. Independent variables are board size measured by taking a dummy variable of equal to 1 if board size is greater than the median board size of the whole sample. Board independence is measured by ratio of independent directors inside the board of directors. CEOCHRM is a dummy variable of equal to 1 if the board chairman is also the CEO of the company. I also consider a dummy variable of Found, if one member at least of the board of director is a founder and zero otherwise. I have also included several other control variables such as multiple trade dummy, which are equal to 1 if more than one director trades, and 0 otherwise. Trade size is the relative trade size measured by the number of shares by an insider divided by the total number shares outstanding at the beginning of the year. I have also incorporated firm characteristics such as size of the firm measured as the last year end market capitalization. Book-to-market is measured by the ratio of book value of equity against market value of equity of the previous year. Return on equity is the last year return on equity of the firm and debt ratio is the previous total debt to total assets. Standard errors are white standard error control for possible heteroscedacity (Hubert-White standard error). 
Table 7. Cross-sectional Regression Model for Insider Sales Relative to Trading Day

CARit $=\alpha i t+\beta 1$ bdsize $+\beta 2$ bdind $+\beta 3$ CEOCHRM $+\beta 6$ FOUND $+\beta 7$ multiple trade $+\beta 8$ tsize $+\beta 9$ Size $+\beta 10$ BooktoMarket $+\beta 11$ ROE $+\beta 12$

Debt-equity ratio + eit

\begin{tabular}{|c|c|c|c|c|c|c|c|c|c|c|c|c|}
\hline \multirow[b]{2}{*}{ Variable } & \multicolumn{3}{|c|}{$\operatorname{CAR}(0,20)$} & \multicolumn{3}{|c|}{$\operatorname{CAR}(0,5)$} & \multicolumn{3}{|c|}{$\operatorname{CAR}(0,1)$} & \multicolumn{3}{|c|}{$\operatorname{CAR}(0,20)>0.001$} \\
\hline & Coeff & SE & T-value & Coeff & SE & T-value & Coeff & SE & T-value & Coeff & SE & T-value \\
\hline \multicolumn{13}{|l|}{ Director Identity: } \\
\hline Chairman & -0.049 & 0.007 & $-6.63 * * *$ & -0.006 & 0.007 & -0.91 & -0.017 & 0.003 & $-6.23 * * *$ & -0.045 & 0.009 & $-5.16^{* * *}$ \\
\hline Board Structure: & 0.002 & 0.001 & 1.29 & -0.000 & 0.001 & -0.37 & -0.000 & 0.000 & -0.17 & 0.003 & 0.002 & 1.65 \\
\hline BoardInd & 0.003 & 0.002 & 1.45 & 0.002 & 0.001 & 1.15 & 0.002 & 0.001 & $2.76^{* * *}$ & 0.001 & 0.002 & 0.3 \\
\hline Bdsize & -0.001 & 0.001 & -1.13 & 0.000 & 0.001 & 0.49 & 0.000 & 0.000 & 1.16 & -0.001 & 0.002 & -0.87 \\
\hline \multicolumn{13}{|l|}{ FOUND } \\
\hline Dual & -0.009 & 0.001 & $-6.65 * * *$ & -0.002 & 0.003 & -0.71 & -0.001 & 0.000 & $-2.52 * *$ & -0.011 & 0.002 & $-6.68 * * *$ \\
\hline Control Variables: & 0.128 & 0.168 & 0.76 & -0.303 & 0.038 & $-7.93 * * *$ & -0.008 & 0.053 & -0.15 & 0.111 & 0.169 & 0.66 \\
\hline Multiple Transactions & -0.002 & 0.000 & $-3.19 * * *$ & -0.002 & 0.000 & $-3.92 * * *$ & -0.001 & 0.000 & $-6.32 * * *$ & -0.002 & 0.001 & $-2.86 * * *$ \\
\hline Transaction size & 0.008 & 0.004 & $2.22 * *$ & -0.001 & 0.003 & -0.38 & -0.000 & 0.001 & -0.22 & 0.013 & 0.005 & $2.61^{* * *}$ \\
\hline Size & 0.006 & 0.001 & $4.46^{* * *}$ & 0.003 & 0.002 & $1.67 *$ & 0.001 & 0.000 & $1.91 *$ & 0.007 & 0.001 & $4.77 * * *$ \\
\hline $\mathrm{BM}$ & -0.012 & 0.004 & $-2.95 * * *$ & -0.001 & 0.003 & -0.21 & 0.001 & 0.001 & 0.62 & -0.009 & 0.005 & $-1.74 *$ \\
\hline ROE & 0.098 & 0.007 & $13.06^{* * *}$ & 0.040 & 0.007 & $5.94 * * *$ & 0.0394 & 0.003 & 13.76 & 0.096 & 0.009 & $10.56^{* * *}$ \\
\hline Leverage & Yes & & & Yes & & & Yes & & & Yes & & \\
\hline Constant & Yes & & & Yes & & & Yes & & & Yes & & \\
\hline Industry & 0.107 & & & 0.104 & & & 0.073 & & & 0.099 & & \\
\hline Time & 0.105 & & & 0.098 & & & 0.071 & & & 0.096 & & \\
\hline R-Sqr & $47.25 * * *$ & & & $16.84 * * *$ & & & $30.43 * * *$ & & & $30.83 * * *$ & & \\
\hline Adj-Rsq & 6294 & & & 2338 & & & 6201 & & & 4771 & & \\
\hline F-test & $39.44 * * *$ & & & $27.62 * * *$ & & & $12.86^{* * *}$ & & & $21.95^{* * *}$ & & \\
\hline $\mathrm{N}$ & 1577 & & & 1570 & & & 1564 & & & 573 & & \\
\hline
\end{tabular}

$*, * *$ and $* * *$ denote significance at $10 \%, 5 \%$ and $1 \%$ levels, respectively.

The table shows the relationship between Board Structure and CAR $(0,20)$. CAR $(0,20)$ is from market model size and risk adjusted abnormal returns. Independent variables are board size, measured by taking a dummy variable of equal to 1 if board size is greater than the median board size of the whole sample. Board independence is measured by ratio of independent directors inside the board of directors. CEOCHRM is a dummy variable of equal to 1 if the board chairman is also the CEO of the company. I also consider a dummy variable of Found, if one member at least of the board of director is a founder and zero otherwise. I have also included several other control variables, such as multiple trade dummy, which is equal to 1 if more than one director trade and 0 otherwise. Trade size is the relative trade size measured by the number of shares by an insider divided by the total number shares outstanding at the beginning of the year. I have also incorporate firm characteristics, such as size of the firm measured as the last year end market capitalization. Book -to-market is measured by the ratio of book value of equity against market value of equity of the last year. Return on equity is the last year return on equity of the firm and debt ratio is the previous total debt to total assets. Standard errors are white standard error control for possible heteroscedacity (Hubert-white standard errors).

Other variables, such as size of the firm measured by year end market capitalisation, book-to-market ratio and annualised returns on equity shows similar results to the previous insider trading findings (see Table 6 and Table 7). I found that market reactions following insider trading is stronger for smaller size firms with higher bookto-market ratios and higher annualised previous return on equity. In retrospect, the findings corroborate findings of the previous research by showing that small firm sizes have higher market reaction than large firm size [12,19]. Further, my findings in book-to-market ratio suggest that value firm has a stronger market reaction compared to growth firm [1]. This is probably due to higher information asymmetry in the firms with higher book-to-market ratio compared to those with a small book-to-market ratio.

In Table 6 and Table 7, I repeated the analysis in different categories to examine how robust my results were. I discuss this in detail on the robustness test in following section. I also repeated the analysis to take into account the influence of firm characteristics in some of the independent variables. This is because some of the corporate governance variables incorporate firm characteristics (for example, firm size) [10]. I constructed interaction variables to examine if such influence might affect the significance of the key variables. My findings show little changes to what I found in the earlier results as main independent variables appear to confirm our hypothesis that good corporate governance affects market reactions towards insider trading (see Table 8).

I also ran an OLS regression for insider trading activities and company board characteristics. My first hypothesis was that good corporate governance also helps to reduce trading activities associated with future cash flows. I used purchase trading activities as a dependent variable to measure opportunistic trading activities that are associated with future cash flows. I adopted this as a proxy similar to the one used by some prior studies by $[24,25,26]$. This is supported by the theory that insiders with private information may want to utilise the information before it is communicated to the public.

My results in Table 9 show that trading activities measured by purchase ratio are supported by contrarian factors compared to other firm characteristics. I found significant negative relationship between purchase trading activities and firm size. Further, purchase trading activities is positively associated with a higher book-to-market ratio. 
In regards to corporate governance variables, I found that they had no relationship with opportunistic trading activities by insiders.

Table 8. Cross-Sectional Regression Model for Insider Purchase Using Control Variable Relative to Trading Day

CARit $=\alpha i t+\beta 1$ bdsize $+\beta 2$ bdind $+\beta 3$ CEOCHRM $+\beta 6$ FOUND

$+\beta 7 I N F L+\beta 8 E F F+\beta 9$ multiple trade $+\beta 10$ tsize $+\beta 11$ Size $+\beta 12$

BooktoMarket $+\beta 13$ ROE $+\beta 14$ Debt-equity ratio + eit

\begin{tabular}{cccc}
\hline \multicolumn{3}{c}{$\operatorname{CAR}(0,20)$} \\
\hline Coeff & SE & T-value
\end{tabular}

Director Identity:

0.017

0.016

1.06

Board Structure:

\begin{tabular}{|c|c|c|c|}
\hline BoardInd & -0.179 & 0.026 & $-6.99 * * *$ \\
\hline Bdsize & 0.027 & 0.008 & $3.2 * * *$ \\
\hline FOUND & 0.006 & 0.006 & 0.95 \\
\hline Dual & -0.008 & 0.004 & $-1.93 * *$ \\
\hline \multicolumn{4}{|l|}{ Interaction Variable: } \\
\hline Board influence & -0.012 & 0.007 & -1.69 \\
\hline Board effective & -0.021 & 0.007 & $-2.7 * * *$ \\
\hline \multicolumn{4}{|l|}{ Control Variables: } \\
\hline Multiple transactions & 0.021 & 0.005 & $3.98 * * *$ \\
\hline Transaction size & -0.021 & 0.212 & -0.1 \\
\hline Size & -0.005 & 0.002 & $-3.43 * * *$ \\
\hline BM & 0.002 & 0.007 & 0.31 \\
\hline ROE & -0.001 & 0.006 & -0.18 \\
\hline Leverage & -0.030 & 0.011 & $-2.61 * * *$ \\
\hline Constant & 0.257 & 0.028 & $9.05 * * *$ \\
\hline Industry & Yes & & \\
\hline Time & Yes & & \\
\hline R-Sqr & 0.292 & & \\
\hline Adj-Rsq & 0.284 & & \\
\hline F-test & $35.79 * * *$ & & \\
\hline $\mathrm{N}$ & 1577 & & \\
\hline
\end{tabular}

$*$,** and $* * *$ denote significance at $10 \%, 5 \%$ and $1 \%$ levels, respectively. The table shows the relationship between Board Structure and CAR $(0$ 20). CAR $(0,20)$ is from market model size and risk adjusted abnormal returns. Independent variables are board size measured by taking a dummy variable of equal to 1 if board size is greater than the median board size of the whole sample. Board independence is measured by ratio of independent directors inside the board of directors. CEOCHRM is a dummy variable of equal to 1 if the board chairman is also the CEO of the company. I also consider a dummy variable of Found, if one member at least of the board of director is a founder and zero otherwise. I have also included several other control variables such as multiple trade dummy, which is equal to 1 if more than one director trade and 0 otherwise. Trade size is the relative trade size measured by the number of shares by an insider divided by the total number shares outstanding at the beginning of the year. I have also incorporated firm characteristics such as size of the firm measured as the last year-end market capitalization. Book-to-market is measured by the ratio of book value of equity against market value of equity of the last year. Return on equity is the last year return on equity of the firm and debt ratio is the previous total debt to total assets. Standard errors are Hubert- white standard error control for possible heteroscedacity. I have also added control variable of board-influence, which is defined as influence of firm size in corporate board. Board effectiveness is defined as the role played by independent director in increasing the size of the board.
Table 9. Determinants of corporate insider trading

\begin{tabular}{|c|c|c|}
\hline Variable & OLS (Buy) & WLS (Buy) \\
\hline \multirow[t]{3}{*}{ Constant } & -0.144 & 0.393 \\
\hline & $(0.148)$ & $(0.279)$ \\
\hline & -0.97 & 1.41 \\
\hline \multirow[t]{3}{*}{ BoardInd } & 0.527 & -0.083 \\
\hline & $(0.131)$ & $(0.295)$ \\
\hline & $4.02 * * *$ & -0.28 \\
\hline \multirow[t]{3}{*}{ Bdsize } & -0.034 & 0.126 \\
\hline & $(0.029)$ & $(0.056)$ \\
\hline & -1.2 & $2.26^{* *}$ \\
\hline \multirow[t]{3}{*}{ Found } & -0.001 & 0.145 \\
\hline & $(0.038)$ & $(0.048)$ \\
\hline & -0.03 & $3.04 * * *$ \\
\hline \multirow[t]{3}{*}{ Dual } & 0.020 & -0.075 \\
\hline & $(0.026)$ & $(0.040)$ \\
\hline & 0.77 & $-1.86^{*}$ \\
\hline \multirow[t]{3}{*}{ Size } & -0.015 & -0.041 \\
\hline & $(0.012)$ & $(0.013)$ \\
\hline & -1.27 & $-3.1 * * *$ \\
\hline \multirow[t]{3}{*}{$\mathrm{BM}$} & 0.134 & 0.267 \\
\hline & $(0.050)$ & $(0.114)$ \\
\hline & $2.71 * * *$ & $2.34 * *$ \\
\hline \multirow[t]{3}{*}{ ROE } & -0.000 & 0.001 \\
\hline & $(0.000)$ & $(0.001)$ \\
\hline & -0.63 & 0.7 \\
\hline \multirow[t]{3}{*}{ Lev } & 0.262 & 0.180 \\
\hline & $(0.087)$ & $(0.155)$ \\
\hline & $3.01 * * *$ & 1.17 \\
\hline Industry & Yes & Yes \\
\hline Year & Yes & Yes \\
\hline $\mathrm{R}-\mathrm{Sq}$ & 0.070 & 0.405 \\
\hline Adj-Rsq & 0.054 & 0.395 \\
\hline F-Test & $4.53^{* * *}$ & $41.03 * * *$ \\
\hline $\mathrm{N}$ & 921 & 921 \\
\hline
\end{tabular}

$*$, ** and $* * *$ denote significance at $10 \%, 5 \%$ and $1 \%$ levels, respectively.

The table shows the relationship between insider purchase ratio and board characteristics of the firm. I have used pooled (time-series and cross-sectional) regression in the light of Jenter (2005) and Bettis et al. (2000) to examine the influence of board characteristics towards insider trading associated with private information. Insider trading is measured by using the ratio of number of shares bought against total shares transacted by insiders in the given fiscal year. The previous tables define all independent variables except board size whereby I use natural logarithm of the number of directors in the board room similar to prior studies for this regression analysis. 
Table 10. Year- by- year distribution of the CAR: The distribution of cumulative abnormal returns on yearly trend

\begin{tabular}{|c|c|c|c|c|}
\hline \multicolumn{5}{|c|}{ Year By Year Distribution Analysis: } \\
\hline \multicolumn{5}{|c|}{ Sell Transactions } \\
\hline Year & (-20 Days CAR) & \%CAR & (+20 DaysCAR) & \%CAR \\
\hline 2000 & 0.02 & 2.35 & -0.03 & -2.72 \\
\hline 2001 & 0.02 & 1.92 & -0.01 & -1.28 \\
\hline 2002 & 0.02 & 1.59 & -0.00 & -0.49 \\
\hline 2003 & 0.01 & 0.68 & -0.01 & -1.36 \\
\hline 2004 & 0.01 & 0.91 & -0.01 & -0.57 \\
\hline 2005 & 0.01 & 0.68 & -0.01 & -0.81 \\
\hline \multicolumn{5}{|c|}{ Buy Transactions } \\
\hline Year & (-20 Days CAR) & $\%$ CAR & (+20 days CAR) & $\%$ CAR \\
\hline 2000 & -0.01 & -0.66 & 0.06 & 5.8 \\
\hline 2001 & -0.03 & -2.63 & 0.03 & 3.1 \\
\hline 2002 & -0.01 & -0.73 & 0.03 & 3.0 \\
\hline 2003 & -0.02 & -1.54 & 0.01 & 1.40 \\
\hline 2004 & -0.02 & -1.69 & 0.01 & 1.45 \\
\hline 2005 & -0.01 & -1.06 & 0.06 & 6.3 \\
\hline
\end{tabular}

The table describe a 20 days before and after stock performance during insider transactions date. Sell transactions is sales of stocks by an insider while purchase is purchase of stock by an insider. CAR is the cumulative average abnormal return) following the transactions of an insider.

\subsection{Robustness Checks}

I repeated my regressions between insider performance using absolute value of CAR against different corporate governance and firm characteristics. In Table 6, I conducted a series of repeated regressions using different windows $(0,5$ and 0,1$)$ to examine whether the effect of different regulations adopted during the sample period might affect the results. This is because SOX was introduced in August, 2002 and had an effect on the reporting period of insiders. Prior to SOX, the reporting period was 40 days after trading by an insider. In 2002 this changed to a two-day reporting period in which insiders are required to report their transactions. I found no significant changes to the explanatory variables. Therefore my results are very robust. My results in Table 6 and Table 7 show that insider purchase of stocks did not create any changes to the terms of the main explanatory variables. I found both board independence, board size and debt level appear to affect market reactions following the trading of an insider in the capital markets. I found similar small changes in my findings in insider sales, whereby only board independence appears to affect market reactions. A logical explanation from this disparity may be due to the fact that the SEC closely monitors sales of stocks by insiders: they appear to pay much more attention to them compared to insider purchasing of stocks [1].

I also ran regression analysis for large transactions undertaken by insiders. I categorised transactions of insiders at $0.1 \%$ compared to the total shares outstanding. I used this to identify whether the magnitude of trading may cause any changes to explanatory variables [1]. I found the results strengthened, supporting my hypothesis that insider performance is affected by the presence of good governance in the corporation.

I retained the $\operatorname{CAR}(0,20)$ as supported by the regulatory requirement that corporate insiders are supposed to report their stocks 40 days from the date of the transactions [1]. However, markets are at best semi-strong, hence the stock price response follows a few days after the transaction date of an insider trade [14].. Sophisticated investors like institutions and market makers may collect this information quickly after the date of the transactions. However, individual stock investors, the majority of investors in the US, obtain such information up to 40 days after the transactions of insiders [1].

I used a different trade metric for insider trading. The net trading metric (the total number of shares purchased minus total number of shares sold) was used as an alternative proxy for measuring insider trading [25]. I considered the number of shares rather than the number of transactions, since the former provides more meaningful information $[19,25,53]$. Furthermore, the amount of trading activity over the long term period may not differ much for several reasons, such as regulatory restrictions, but the volume of shares traded may differ in the long run [53]. Neither metric yielded any different results, nor has it affected our explanatory variables. Hence the results of this paper appear to be robust.

I also conduct a multi-collinearity test since the correlation matrices show that some of the independent variables, such as sales and board size, are highly correlated (see Table 4). One possible explanation is the size effect, whereby large firm sizes lead to larger board sizes. I use a variance inflation factor (VIF) on the independent variable to help us understand whether our results suffered from possible multi-collinearity [54]. Our results show that independent variables appear to have VIF from 0 to 1.63 at the most. This suggests that our results do not suffer from multi-collinearity [54]. [55] argues that there is a margin of tolerance between $\mathrm{VIF}=0$ to $\mathrm{VIF}=4.9$ in which multi-collinearity is not a problem in the regression model.

\section{Conclusion}

This paper has analysed the relationship between insider trading and firm governance characteristics. The rationale for such an empirical study is that whilst corporate governance research has provided evidence to 
suggest that corporate governance has been effective in enhancing information disclosure and quantity in the capital markets, there is a lack of analysis as to whether these measures help to reduce information asymmetry in the capital markets. In this paper we have used insider trading as a proxy for asymmetric information, and I have linked the corporate governance variables essential to information disclosure with insider trading activities and abnormal profits.

I analysed the role of the board size of the firm, independent directors, and debt holders on insider trading signals. In doing so, I focused on insider trading abnormal returns following the transactions date. The results show that market reactions following insider transactions are significant and negatively associated with the board independence ratio and debt level, and are positively associated with board size. Likewise, for sales transactions, the relationship appears to strongly support board independence and debt holders. For trading activities, the results suggest that insider trading activities do not have a significant relationship with corporate governance characteristics. These results appear to show board variables that are strongly associated with disclosures such debt level and independent directors deter insider abnormal performance in the market. This means board independence will help market regulators in enhancing disclosure, exercise transparent policies which could help to reduce insider performance. What surprised us we found insider trading activities had no relationship with these variables as well. This finding of no significant relationship between board and insider trading activities raise also the importance of selecting competent board members to advise and supervise management. An independent director may be an important tool for monitoring management but may lack competence, rigor and essential skills to understand the complex operations issue in the company.

\section{References}

[1] FIDRMUC, J., GOERGEN, M. \& RENNEBOOG, L. (2006). Insider Trading, News Releases and Ownership Concentrations. Journal of Finance, 61

[2] HILliER, D. \& MARSHALL, A. P. (2002a). Are Trading Ban Effective: Exchange, Regulation and Corporate insider Transactions around earnings announcement. Journal of Corporate Finance, 8 , 393-410.

[3] GARFINKEL, A. J. (1997). New Evidence on the effects of Federal Regulations on insider trading: The Insider Trading and Security Fraud Enforcement Act (ITSFEA). Journal of Corporate Finance.

[4] KAlluNKI, P.-J., NILSSON, H. \& HELlSTROM, J. (2009). Why do insider trade? Evidence based on unique data on Swedish insiders. Journal of Accounting and Economics, 48 37-53.

[5] BETZER, A. \& THEISSEN, E. (2009). Insider Trading and Corporate Governance: The Case of Germany. European Financial Management, 15, 402-429.

[6] BetTis, J. C., COLES, J. L. \& LEMMON, M. L. (2000). Corporate Policies Restricting trading by insiders. Journal of Financial Economics, 57.

[7] KLEIN, A. (2002). Audit Committee, board of director characteristics and earnings management. Journal of Accounting and Economics, 33, 375-400.

[8] RAVINA, E. \& SAPIENZA, P. (2009). What do Independent Directors Know? Evidence from their Trading. Review of Financial Studies.
[9] SUMMERS, S. L. \& SWEENEY, J. T. (1998). Fraudlent Misstated Financial Statements and Insider Trading: An Empirical Analysis. The Accounting Review.

[10] ANDERSON, R. C., MANSI, S. A. \& REEB, M. A. (2004). Board Characteristics, Accounting report integrity and the cost of debt. Journal of Accounting and Economics, 37.

[11] YERMACK, D. (1996). Higher market valuation of companies with a small board of directors. Journal of Financial Economics, 40, 185-211.

[12] SEYHUN, H. N. (1986). Insider's Profit, Cost of Trading and Market Efficiency. Journal of Financial Economics.

[13] FREIDERICH, S., GREGORY, M., MATATKO, J. \& TONKS, I. (2002). Short-run Returns around the trades of Corporate insiders on the London Stock Exchange. European Financial Management 8.

[14] HILliER, D. \& MARSHALL, A. P. (2002b). The Market Evaluation of Information in Directors Trades. Journal of Business Finance and Accounting, 29.

[15] KE, B., HUDDART, S. \& PETTRONI, K. (2003). what insiders know about the future earnings and how they use it: Evidence from insider trades. Journal of Accounting and Economics, 35.

[16] FRANKEL, R. \& LI, X. (2004). Characteristics of a firm's information environment and the information asymmetry between insiders and outsiders. Journal of Accounting and Economics, 37, 229-259.

[17] CAI, C., KEASEY, K. \& SHORT, H. (2006). Corporate Governance and Information Efficiency in Security Markets. European Financial Management, 12, 763-787.

[18] JAFFE, J. F. (1974b). Special Information on Insider Trading. Journal of Business, 47.

[19] SEYHUN, H. N. (2000). Investment Intelligence, MIT Press.

[20] HODGSON, A. \& VAN PRAAG, B. (2006). Information trading by corporate insiders based on the accounting accruals: Forecasting economic performance. Journal of Accounting and Finance, 46, 819-842.

[21] ROULSTONE, D. T. (2003). The Relation Between InsiderTrading Restrictions and Executive Compensation. Journal of Accounting Research, 41, 525-551.

[22] KEASEY, K., THOMPSON, S. \& WRIGHT, M. (2005). Corporate Governance, Accountability, Enterprise and International Comparison, John Willey \& Sons Ltd.

[23] LAKONISHOK, J. \& LEE, I. (2001). Are insider trades informative. Review of Financial Studies, 14, 79-112.

[24] ROZEFF, S. M. \& ZAMAN, M. A. (1998). Overreaction and insider trading: Evidence from growth and value portfolios. Journal of Finance, 53.

[25] ROULSTONE, D. \& PIOTROSKI, J. D. (2005). Do insider trades reflect both contrarian beliefs and superior knowledge about future cash flow realizations. Journal of Accounting and Economics, 39, 55-82.

[26] ZHANG, W., CAHAN, S. F. \& ALLEN, A. C. (2005). Insider Trading and Pay-Performance Sensitivity: An Empirical Analysis. Journal of Business Finance and Accounting, 32, 306-686.

[27] MEULBROEK, L. (1992). An Empirical analysis of illegal insider trading. Journal of Finance, 47.

[28] GAILLARD, E. (1992). Insider Trading, Kluwer Law and Taxation Publishers.

[29] JENSEN, M. C. \& FAMA, E. F. (1983). Separation of Ownership and Control. Journal of Law and Economics, 26, 301-325.

[30] SCHLEIFER, A. \& VISHNY (1997). A Survey of Corporate Governance. Journal of Finance, 52, 737-783.

[31] BERLE, A. A. \& MEANS, G. C. (1932). The Modern Corporation and Private Property, New York, Macmillan.

[32] HUDDART, S., KE, B. \& SHI, C. (2007). Jeopardy, non-public information and insider trading around SEC $10-\mathrm{K}$ and $10-\mathrm{Q}$ fillings. Journal of Accounting and Economics, 43, 3-36.

[33] EASLEY, D. \& O'HARA, M. (2004). Information and Cost of Capital. Journal of Finance, 59, 1553-1583.

[34] ABOODY, D. \& LEV, B. (2000). Information Asymmetry, R\&D and Insider Gains. Journal of Finance, 58.

[35] ABOODY, D., HUGHES, J. \& LIU, J. (2005). Earnings Quality, Insider Trading and Cost of Capital. Journal of Accounting Research, Vol 43.

[36] BENY, L. (2007). Insider Trading Law and Stock Markets around the World: An Empirical contribution to the Theoretical and Economic Debate. Journal of Corporation Law, 32, 237-300. 
[37] KARAMANOU, I. \& VAFEAS, N. (2005). The association between corporate boards, audit committees, and management forecasts: An empirical analysis. Journal of Accounting Research, 43, 453-486.

[38] JENSEN, M. C. \& MECKLING, H. L. (1976). Theory of Firm: Agency Costs, Managerial Behaviour and Ownership Structure. Journal of Financial Economics, 3, 305-360.

[39] DALTON, D. R. \& KESNER, I. F. (1987). Composition and CEO duality in the Board of Directors: An International Perspective. Journal of International Business Studies, 18, 33-42.

[40] FORKER, J. J. (1992). Corporate Governance and Disclosure Quality. Accounting \& Business Research, 22, 111-124.

[41] BERK, J. \& DEMARZO, P. (2007). Corporate Finance, Addison Wesley.

[42] WEIR, C., LAING, D. \& MCKNIGHT, J. P. (2002). Internal and External Governance Mechanism: Their Impact on the performance of Large UK Public Companies. Journal of Business Finance and Accounting, 29, 306-686.

[43] BROWN, P. \& KENNELLY, W. J. (1972). The Informational Content of Quartely Earnings: An Extension and Some Further Evidence. The Journal of Business, 45, 403-415.

[44] BROWN, S., HILLIEGEIST, S. A. \& LO, K. (2009). The effect of earnings suprises on information asymmetry. Journal of Accounting and Economics, 47, 208-225.

[45] DIMSON, E. \& MARSH, P. (1986). Event study methodologies and size effect. Journal of Financial Economics, 17, 113-142.

[46] GREGORY, M., MATATKO, J. \& TONKS, I. (1997). Detecting Information from directors' trades: Signal definition variable size effects. Journal of Business Finance and Accounting.
[47] BOEHMER, E., MUSUMECI, J. \& POULSEN, A. B. (1991) Event study methodology under conditions of event induced variance. Journal of Financial Economics, 3, 233-272.

[48] FREIDERICH, S., GREGORY, M., MATATKO, J. \& TONKS, I. (2002). Short-run Returns around the trades of Corporate insiders on the London Stock Exchange. European Financial Management 8.

[49] CHENG, Q. \& LO, K. (2006) Insider Trading and Voluntary Disclosure. Journal of Accounting Research, 44.

[50] BENEISH, M. D. \& VARGUS, M. (2002) Insider Trading, earnings quality and accruals misspricing. The Accounting Review, 77, 755-792.

[51] YERMACK, D. (1996) Higher market valuation of companies with a small board of directors. Journal of Financial Economics, 40, 185-211.

[52] EASLEY, D. \& O'HARA, M. (1987) Price, Trade size and Information on Securities Markets. Journal of Financial Economics, 19.

[53] OFEK, E. \& YERMACK, D. (2000) Taking Stock Equity Based Compensation and Evolution of Managerial Compensation. Journal of Finance, 58, 1367-1384.

[54] CHEUNG, L. T. W. \& LEUNG, T. Y. (2008) Is there information content from insider trading activities preceding earnings and dividend announcements in Hong Kong. Accounting and Finance 48, 417-437.

[55] OBRIEN, R. (2007) A caution regarding the rule of thumb for variance inflation factors. Quality and Quantity, 41, 673-690. 